\title{
Sediment distribution and transport in the shallow coastal waters along the west coast of Denmark
}

\author{
Jørgen O. Leth, Birger Larsen and Dennis Anthony
}

Until recently, studies of the regional distribution of seabed sediments off the littoral zone of the Danish North Sea coast had been concentrated on the Jutland Bank area (Fig. 1; Leth 1996, 1998). Knowledge on the sedimentary conditions and processes along the entire west coast of Jutland has, however, significantly increased as a result of $2000 \mathrm{~km}$ of newly acquired high-resolution seismic and side-scan sonar data, supplemented by about 100 vibrocores. These data were collected by the Geological Survey of Denmark and Greenland (GEUS) during joint projects with the Danish Coastal Authority between 1998 and 2001 (Leth et al. 1999; Larsen \& Leth 2001).

The coastal zone off west Jutland displays a highly dynamic environment, where sediment transport is governed by strong tidal and wave-induced currents. The net wavegenerated current is south going, while the coastal current has a net direction towards the north (Knudsen et al. 2002). The direction of the net littoral drift is southward from the outlet of Limfjorden to Blåvands Huk, with net erosion north of Nymindegab and aggregation to the south; the offshore part of this depositional system has recently been studied (Larsen \& Leth 2001).

\section{Seabed geology}

The present coast between Nymindegab and Limfjorden is a highly erosive, wave-dominated, high-energy barrier coast subdivided by glacial headlands. The natural retreat of the coast profile is in the order of 2-5 m/year. Mapping of the geological substratum reveals a complex range of lithologies, of which five types are dominant: (1) Weichselian glacial till, (2) Saalian till, (3) Weichselian outwash deposits, (4) Eemian marine deposits and (5) Miocene sediments (Fig. 2). The development of the coast and sand transport has been closely linked to the subsurface geology since the onset of the Holocene transgression and up to the present (Leth 1996, 1998; Anthony et al. in press).

\section{Distribution and transport of mobile sand}

North of Nymindegab the thickness and regional distribution of the upper layer of fine- to medium-grained marine sand have been mapped (Fig. 3). The accumulations can be
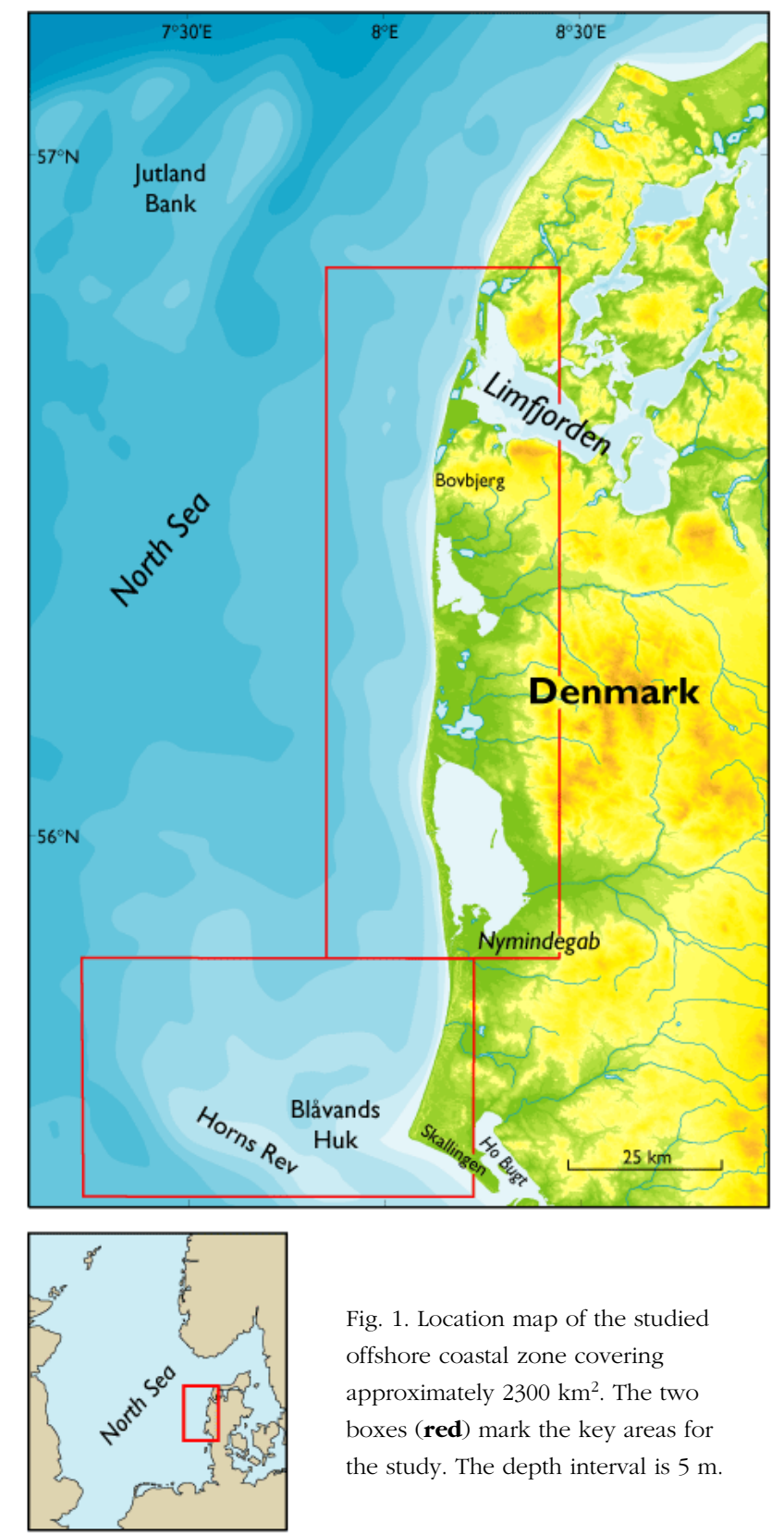

Fig. 1. Location map of the studied offshore coastal zone covering approximately $2300 \mathrm{~km}^{2}$. The two boxes (red) mark the key areas for the study. The depth interval is $5 \mathrm{~m}$.

considered as positive morphological forms. Twelve samples from the sand have yielded dates from 150 to 835 years B.P. (calibrated C-14 radiocarbon ages). The sand unit is therefore regarded as mobile sand representing the recent to subrecent hydrographic regime. A regional erosional uncon- 


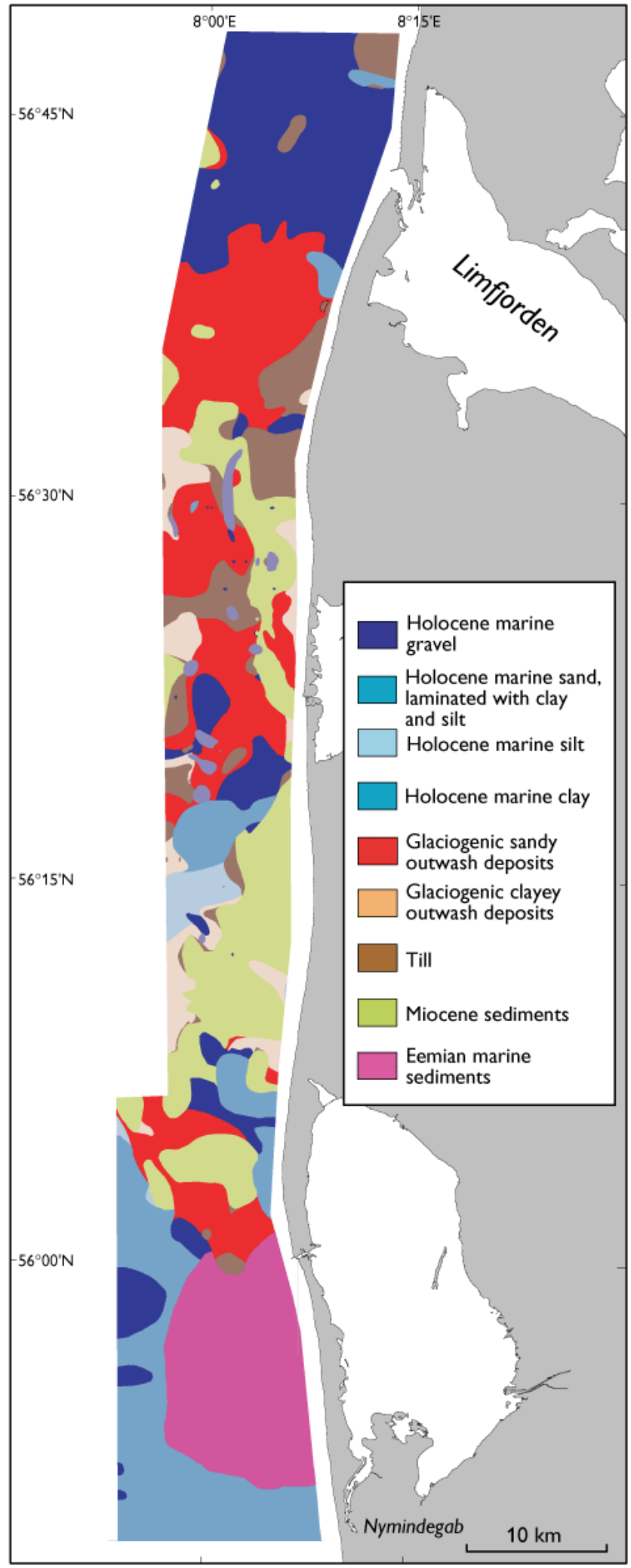

Fig. 2. Map showing the seabed geology below the mobile sand layer.

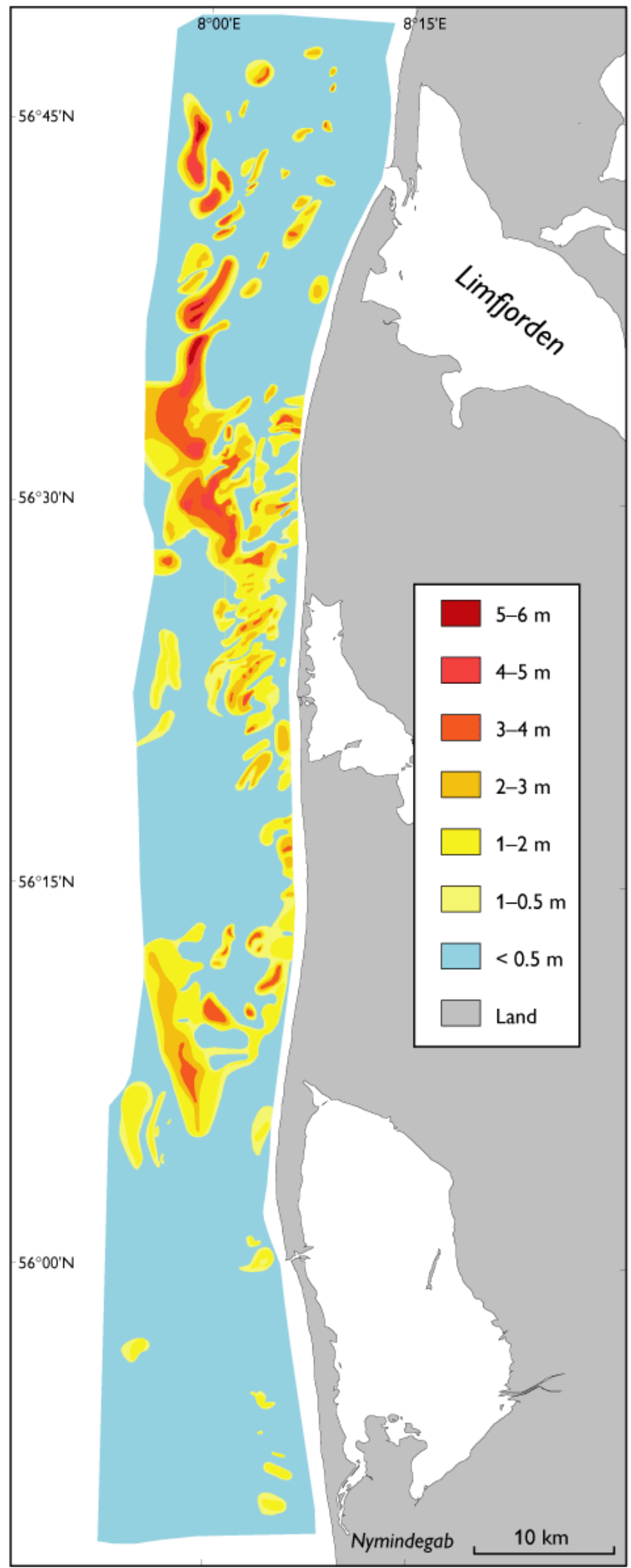

Fig. 3. Map showing the thickness and distribution of the mobile sand layer. 
formity underlying the sand layer suggests that the hydrodynamic energy level in the coastal zone may have increased within the past millennium. As the unit is less than $0.5 \mathrm{~m}$ thick in most of the study area, the sand available for sediment transport in the area is obviously limited. However, the mobile sand occurs as NE-SW-trending shoreface-connected ridges close to the coast between Nymindegab and Bovbjerg (Anthony \& Leth 2002) that extend into large sand-bodies farther offshore. The formation of two large sand accumulation areas, 15 and $30 \mathrm{~km}$ long and with a NNW-SSE trend, is not clearly understood (Fig. 3). Their existence is most likely due to a combination of a hydrographically controlled sediment transport pattern and the presence on the nearby seabed of sandy outwash deposits. Due to the young age of the deposits and the shape of present bedforms, it is suggested that the Jutland coastal current is the major agent responsible for the reworking and redistribution. The overall oblique form of the sand relative to the coast is explained by the fact that the offshore NNW-directed tidal flood current is stronger than the tidal ebb current. That the northern sand body is much larger than the southern seems to reflect the general northwards decrease of the tidal strength, leading to a decrease in tidal current sediment transport capacity towards the north, and thus net deposition. It is probable that a sediment transport system interacting between the study area and the adjacent area further west exists, but to test this more research is needed.

\section{The prograding coast}

The coast south of Nymindegab is aggrading at about $0.5-2$ $\mathrm{m} /$ year. Over a distance of $25 \mathrm{~km}$ it has prograded some $3 \mathrm{~km}$ westwards in the form of a beach ridge system during the last 3000 years (Nielsen et al. 1995; Larsen \& Andersen in press). The development of the back-barrier area from 8000 to 3000 years B.P. is not well known because of the $5-10 \mathrm{~m}$ thick cover of aeolian sand. Most of the deposition in this area took place in lagoons, like that of the present day Ho Bugt, in lakes dammed between the littoral deposits and the Saalian landscape, or in the form of large dunes and cover sands. The south-east-trending peninsula Skallingen is a very young (after A.D. 1600) analogue to a barrier island. The westwardprotruding bank of inner Horns Rev belongs to the same system. Blåvands Huk forms the centre of a major sand accumulation area some $25 \mathrm{~km}$ long, 5-15 km wide and $15-25 \mathrm{~m}$ thick, with a total volume of about $6 \mathrm{~km}^{3}$. This Holocene spit complex is built out onto an erosional, very flat platform at about $20 \mathrm{~m}$ below present sea level, west of the old Saalian glacial landscape. The whole complex has accumulated steadily throughout the past 8000 years, and is still very active.

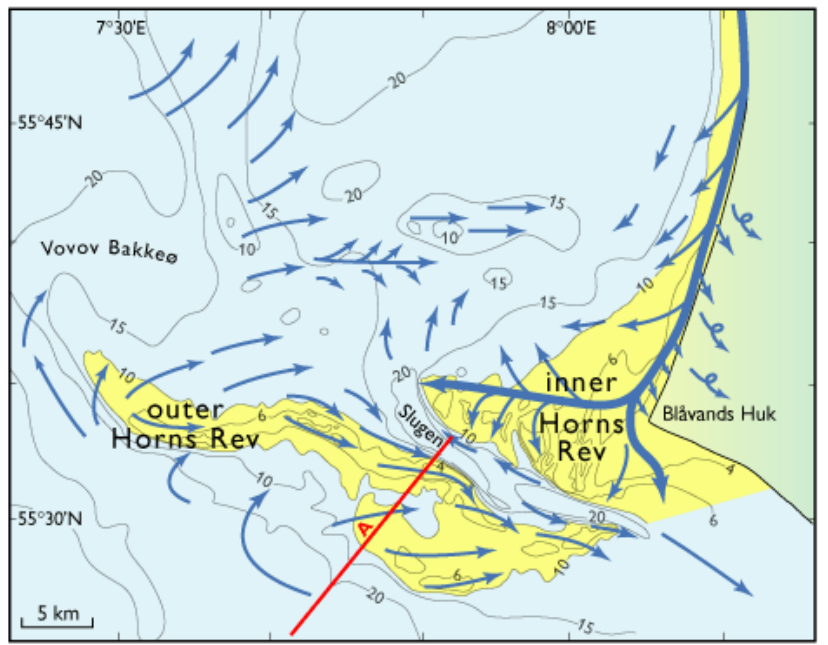

Fig. 4. Sediment transport directions for the Holocene marine sand determined from direction of sediment structures, distribution of sediment thickness and modelling of recent sediment transport by the Danish Hydraulic Institute. A: section shown in Fig. 5.

Inner Horns Rev is a $6 \mathrm{~km}$ wide and $20 \mathrm{~km}$ long bank protruding westwards from Blåvands Huk (Fig. 4). New investigations indicate that it is highly dynamic, with active sand accumulation particularly on the slopes. The direction of progradation suggests longshore sediment transport (Fig. 4). C-14 datings suggest that it has prograded some $3.5 \mathrm{~km}$ westwards during the last 800 years.

The shape of the Blåvands Huk spit complex is due to a combination of wave-dominated longshore sediment transport from the north, tidal influence and the partial shelter from the offshore banks at Horns Rev. According to recent estimates by the Danish Coastal Authority (Kystdirektoratet 2001), some 2.3 million $\mathrm{m}^{3}$ of sediments are supplied annually to the system from the north.

A second accumulation system is located at the outer Horns Rev to the south-west (Fig. 4). This is separated from the inner Horns Rev by the channel Slugen. The base of Horns Rev is an erosional unconformity on top of Eemian marine silt in the central part, and on Saalian glacial deposits further to the west. A wide valley has been cut into Eemian deposits and subsequently filled with Weichselian glaciofluvial deposits, with remnants of small Lower Holocene bogs on the top (Fig. 5).

From the present study it is now clear that Horns Rev consists of Holocene sand with gravel deposited after the sea transgressed the area in Early Holocene time, about 8500 years B.P., and is not a Saalian terminal moraine as has been previously proposed. Precisely how the outer Horns Rev has formed is not clear, but all sediment structures suggest westerly sediment transport. At southern Horns Rev the lower 


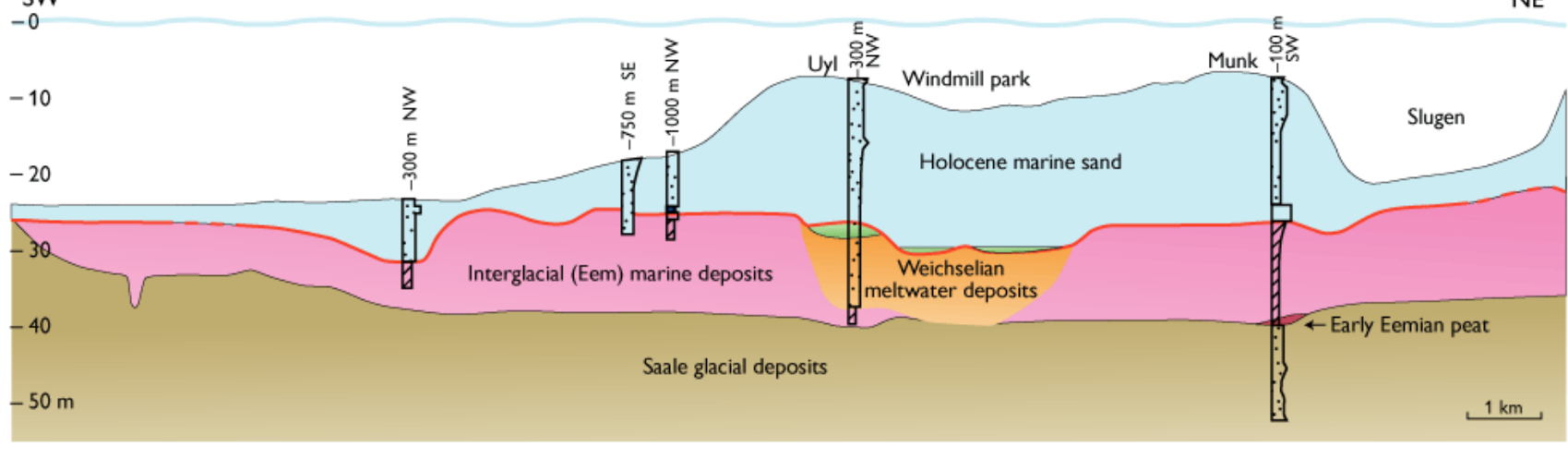

Fig. 5. Geological cross-section of outer Horns Rev. Location shown on Fig. 4. The numbers above each borehole indicates displacement relative to cross-section.

part is a complex of gravel-rich spits that have grown towards the east-north-east. Prograding reflectors and sand waves also suggest a net eastward aggradation. This is in agreement with the annual average direction and magnitude of recent sediment transport, as modelled by the Danish Hydraulic Institute (DHI). On a day-to-day basis the sediment transport is very variable, in response to the strong tidal currents and the breaking waves. Sediment transport from a westsouth-westerly direction is also indicated by the direction of progradation and the now buried spits in the up to $15 \mathrm{~m}$ thick Holocene successions further to the north. The net direction of sediment transport based on this evidence is shown in Fig. 4.

The Blàvands Huk - Horns Rev area has been a major depocenter for sediments transported southwards along the west coast, as well as material presumably eroded from the floor of the North Sea, in spite of the very exposed setting.

\section{References}

Anthony, D. \& Leth, J.O. 2002: Large-scale bedforms, sediment distribution and sand mobility in the eastern North Sea off the Danish west coast. Marine Geology 182, 247-263.

Anthony, D., Leth, J.O., Konradi, P. \& Andersen, L.T. in press: Shallow seabed geology and paleogeography off the Danish North Sea coast. Boreas.
Knudsen, S.B., Laustrup, C., Madsen, H.T. \& Christensen, E.D. 2002: Sediment transport in the outer part of the coastal profile, 1-13. 28th International Conference on Coastal Engineering, Cardiff, Wales.

Kystdirektoratet 2001: Kystdirektoratets program for undersøgelser og udvikling, 1998-2001, Slutrapport, 36 pp. Lemvig: Kystdirektoratets Kysttekniske Afdeling.

Larsen, B. \& Andersen, L.T. in press: Late Quaternary stratigraphy and morphogenesis in the eastern North Sea: Horns Rev and Fanoe Bay area and its relation to onshore geology. Netherlands Journal of Geosciences.

Larsen, B. \& Leth, J.O. 2001: Regionalgeologisk tolkning og en samlet vurdering af aflejringsforholdene i området mellem Nymindegab og Horns Rev. Danmarks og Grønlands Geologiske Undersøgelse Rapport 2001/96, 83 pp.

Leth, J.O. 1996: Late Quaternary geological development of the Jutland Bank and the initiation of the Jutland Current, NE North Sea. Geological Survey of Norway Bulletin 430, 25-34.

Leth, J.O. 1998: Late Quaternary geology and recent sedimentary processes of the Jutland Bank region, NE North Sea, 173 pp. Unpublished Ph.D. thesis, University of Aarhus, Denmark.

Leth, J.O., Anthony, D., Andersen, L.T. \& Jensen, J.B. 1999: Geologisk kortlægning af Vestkysten. Regionalgeologisk tolkning af kystzonen mellem Lodbjerg og Nymindegab. Danmarks og Grønlands Geologiske Undersøgelse Rapport 1999/75, 29 pp.

Nielsen, S.T., Andreasen, F. \& Clemmensen, L.B. 1995: The middle and late Holocene barrier spit system at Vejers, Denmark: structure and development. Bulletin of the Geological Society of Denmark 42, $105-119$.

\section{Authors' addresses}

J.O.L. \& B.L., Geological Survey of Denmark and Greenland, Øster Voldgade 10, DK-1350 Copenhagen K, Denmark. E-mail: jol@geus.dk D.A., Royal Danish Administration of Navigation and Hydrography, Overgaden o. Vandet 62 B, P.O. Box 1919, DK-1023 Copenhagen $K$, Denmark. 